Article

\title{
The Importance of Institutional Design for Distributed Local-level Governance of Groundwater: The Case of California's Sustainable Groundwater Management Act
}

\author{
Michael Kiparsky ${ }^{1, *}$ (D), Anita Milman ${ }^{2}$ (D), Dave Owen ${ }^{3}$ and Andrew T. Fisher ${ }^{4}$ \\ 1 Wheeler Water Institute, Center for Law, Energy \& the Environment, School of Law, \\ University of California at Berkeley, Berkeley, CA 94720-7200, USA \\ 2 Department of Environmental Conservation, University of Massachusetts, Amherst, MA 01003, USA; \\ amilman@eco.umass.edu \\ 3 Hastings College of the Law, University of California, San Francisco, CA 94102, USA; \\ owendave@uchastings.edu \\ 4 Department of Earth and Planetary Sciences, University of California, Santa Cruz, CA 95064, USA; \\ afisher@ucsc.edu \\ * Correspondence: kiparsky@berkeley.edu; Tel.: +1-415-806-6656
}

Received: 31 July 2017; Accepted: 25 September 2017; Published: 30 September 2017

\begin{abstract}
In many areas of the world, groundwater resources are increasingly stressed, and unsustainable use has become common. Where existing mechanisms for governing groundwater are ineffective or nonexistent, new ones need to be developed. Local level groundwater governance provides an intriguing alternative to top-down models, with the promise of enabling management to better match the diversity of physical and social conditions in groundwater basins. One such example is emerging in California, USA, where new state law requires new local agencies to self-organize and act to achieve sustainable groundwater management. In this article, we draw on insights from research on common pool resource management and natural resources governance to develop guidelines for institutional design for local groundwater governance, grounded in California's developing experience. We offer nine criteria that can be used as principles or standards in the evaluation of institutional design for local level groundwater governance: scale, human capacity, funding, authority, independence, representation, participation, accountability, and transparency. We assert that local governance holds promise as an alternative to centralized governance in some settings but that its success will depend heavily on the details of its implementation. Further, for local implementation to achieve its promise, there remain important complementary roles for centralized governance. California's developing experience with local level groundwater management in dozens of basins across the state provides a unique opportunity to test and assess the importance and influence of these criteria.
\end{abstract}

Keywords: groundwater; governance; institutional design; sustainability; management; SGMA

\section{Introduction}

Groundwater is an increasingly important and increasingly stressed resource. Globally, groundwater provides half of the human drinking water supply and more than $40 \%$ of the irrigation water used for agriculture [1-3]. In many regions, groundwater withdrawals have depleted the resource [4,5], with the impacts including lower groundwater levels, reductions in groundwater storage, salt-water intrusion, degraded water quality, land subsidence, and declining flows in interconnected 
surface waters. The global proliferation of such impacts, combined with the fact that some of this degradation is irreversible, has to led to concern that a 'global groundwater crisis' is emerging $[1,6]$.

In many areas around the world, governance systems for groundwater are either absent or insufficient to ensure the long-term health of humanity and ecosystems [7-11]. The task of creating effective governance systems presents significant challenges. Governing groundwater effectively requires consideration of the full set of organizations, structures, rules, and processes that influence or control human actions impacting physical groundwater systems [12-14]. This includes attention to not only the operational rules that influence day-to-day practice, but also the constitutional and collective choice rules that determine how policies are formulated, enacted, and enforced and who is involved in that process $[15,16]$.

Since institutions provide "the principal pillar on which governance rests" [17] one of the most important challenges is determining the appropriate institutional level(s) at which to locate governance. That debate often pits advocates of centralized control against advocates of more localized governance, with each approach offering potential benefits and pitfalls. Across many states in the western USA, groundwater governance is situated at the state-level, though existing legal frameworks are incomplete and authority is fragmented $[8,18]$. Proposals for centralized governance can generate political opposition, as concerns arise about fairness, inefficiency, insensitivity to local conditions, and potential changes to current water use practices $[9,19,20]$. The collective management of groundwater by water users themselves may promise greater buy-in than top-down approaches [9], but groundwater is often a highly politicized, common-pool resource, which can inhibit the voluntary development of effective local governance. Groundwater users therefore may choose not to change the status quo. Additionally, preferences for local control can collide with the need for coordination within and between groundwater basins. These tensions suggest the potential for a combination of harmonization, where centralized rules are standardized broadly, and subsidiarity, where decisions are delegated to the lowest possible scale of governance [21].

With passage of the Sustainable Groundwater Management Act (SGMA, see below) in 2014, California has undertaken a novel, hybrid approach to overcoming the tensions inherent between local and statewide groundwater governance. SGMA is notable not only as California's first statewide framework for groundwater governance but also because it functions by devolving substantial authority and responsibility to the local level, within the confines of physically defined sustainability goals supported by state oversight and enforcement. The structure of SGMA is therefore interesting as a conceptual alternative for groundwater governance that provides for local level self-determination, yet has state-level regulatory backing to ensure that local level collective action will occur.

California's new approach to groundwater governance provides both a test and a potential template for other regions to consider, should it prove to be successful. SGMA's effectiveness will depend on many aspects of its implementation [17], including, crucially, the development of new local-level institutions for groundwater governance. SGMA's legislative framework grants local entities and stakeholders considerable leeway in designing these new local level institutions and in defining the bases for evaluating success. Decisions regarding the design of these new institutions will have important consequences for their ability develop knowledge of the physical groundwater system; set objectives; develop, implement, gain support for, and enforce policies; and adapt to changes over time [22-25].

In this article, we describe critical institutional design decisions and examine key design challenges facing local entities engaging in groundwater governance in California. Our analysis expands the focus of a growing scholarly discussion on the legal and policy contexts of SGMA by highlighting the importance of institutional design and its influence on decision-making and implementation [18,25,26]. We do not advocate for specific policies for groundwater management but instead pose considerations stemming from the broader governance context and define their impacts on policy selection and implementation. In doing so, we shed light on factors that will be important for other regions that may consider this approach, following California's novel approach to multi-level groundwater governance. 
The article proceeds as follows. First, we briefly describe the structure and notable features of SGMA (Section 2). Second, we briefly review the theories and concepts of governance and institutional design that apply to groundwater (Sections 3 and 4). Third, we describe some of the hurdles that may emerge for governance and institutional design based on a critical examination of the SGMA model and suggest how effective local groundwater governance might overcome these challenges (Sections 5-7). Finally, we describe how these criteria and systems could apply in California as it develops new Groundwater Sustainability Agencies (Section 8), emphasizing that, while this discussion focuses on local agencies, there remain important roles for external entities and centralized governance, both within and beyond California's groundwater regulation system.

\section{Basics of SGMA and California Groundwater}

California groundwater law was based for years on the fiction that groundwater and surface water were separate systems, with only minimal attempts toward integrative regulation $[27,28]$. The state's surface water law system combines riparian rights (for parcels adjacent to waterways) and appropriative rights (for water allocated based on the historical order of withdrawals from rivers and streams) [29]. Both the rights and the operation of related infrastructure are subject to a complex mix of federal and state regulatory law, much of it designed to protect the natural environment and much of it unsettled after decades of litigation [29]. In contrast, until recently, groundwater use in California was scarcely regulated on a statewide basis [27]. Groundwater regulation also was left almost exclusively to the discretion of local governments or courts, with state government declining to enter the regulatory field. Some local governments, particularly in urban southern California, enacted robust regulatory schemes [30,31]. In a few basins, courts adjudicated groundwater rights [31,32], but, in much of California, groundwater use regulation remained minimal, even as the state consumed increasing and unsustainable amounts of groundwater.

The passage of SGMA transformed this legal regime. SGMA sets a state policy of sustainably managing groundwater resources. SMGA defines sustainable groundwater management as the 'management and use of groundwater in a manner that can be maintained during the 50-year planning and implementation horizon without causing undesirable results' [33]. The six undesirable results are 'significant and unreasonable':

1. depletion of supply, indicated by chronic lowering of groundwater levels;

2. reduction of groundwater storage;

3. seawater intrusion;

4. degraded water quality;

5. land subsidence that substantially interferes with surface land uses; and

6. adverse impacts on the beneficial uses of interconnected surface water due to depletions [34].

To achieve this goal, SGMA delegates responsibility to new local agencies that are to be self-organized by local public entities. These Groundwater Sustainability Agencies (GSAs) will be responsible for the development and implementation of Groundwater Sustainability Plans (GSPs). GSPs generally must include measurable objectives with interim milestones designed to achieve sustainability within twenty years of plan implementation [35]. SGMA offers GSAs a broad array of authorities to help them carry out their responsibilities and leaves them substantial flexibility in deciding how to do so. SGMA also sets a backstop of state-level oversight, providing for state intervention if local agencies are unable or unwilling to carry out their responsibilities, and enforcement and sanctions to ensure that the planning and implementation achieve the goals of the legislation [36]. In addition, some degree of central control is retained; for example, by requiring approval from the state Department of Water Resources for locally developed plans. SGMA thus replaces a regime in which groundwater regulation occurred primarily at the discretion of local governments with one in which local governance is both required and supported by state law and is backstopped by the possibility of direct state oversight. 
The many challenges that await California in its implementation of SGMA are also affected by its timeline [37]. From the date of effective legislation on 1 January 2015, notable milestones for the Department of Water Resources include frontloaded requirements for analysis and the implementation of best management practices by 1 January 2017. For local entities, key milestones include the establishment of governance entities by 30 June 2017 and the management of groundwater basins under sustainability plans by 2020 or 2022, depending on the basin condition. Sustainability is to be achieved within 20 years of plan implementation.

\section{Groundwater Governance}

SGMA's new legal regime is novel and important [26,28]; it creates explicit and implicit requirements for the development of multi-level groundwater governance across the state. SGMA assigns responsibility to the local-level not only for managing groundwater but also for many decisions about the institutional design of the governance systems necessary to carry out SGMA's mandate. The institutional design of groundwater governance systems will be critical to their effectiveness, as it determines processes and capacities for decision-making, implementation, and the enforcement of groundwater management activities [16].

Some general observations about groundwater governance are reflected, explicitly or implicitly, in SGMA and are relevant to arguments about institutional design. For groundwater governance to be effective, there must be knowledge of the groundwater system; the setting of objectives and a plan for management; and the implementation of an accepted plan. Unfortunately, many aspects of groundwater systems are often poorly understood. For example, the spatial boundaries of primary aquifers are often weakly defined [38,39]. Responses to pumping or differences in aquifer conditions can vary profoundly even within a single groundwater basin [40-42]. Natural groundwater inflows and outflows are difficult to measure and monitor, and groundwater extraction is difficult to measure or control for hydro-social reasons [43]. The net result is hydrogeologic uncertainty, often amplified by substantial time lags between causes and effects [44]. Lastly, institutional structures, including fragmented and overlapping jurisdictions and responsibilities over surface water and groundwater, water and land, and other socially-constructed separations, can constrain the collection and sharing of data and knowledge $[9,45]$. Thus, groundwater agencies need to be designed in such a way that they are capable of managing heterogeneous data, developing new knowledge, and evaluating the state of the groundwater basins they are to govern.

Groundwater governance also requires a plan for groundwater management, including allocations among competing users over space and time. Broadly speaking, the water balance in a groundwater basin can be improved through demand reduction or supply augmentation, with the latter including the development of alternative sources of water for consumptive use or increasing aquifer recharge from storm flows, recycled water, or other sources. Combinations of these strategies will vary among basins, with specifics sometimes influenced by water quality objectives. Successful plans often require changes in water use. Since groundwater and surface water are often physically connected, an effective plan will also require balancing the interests of groundwater users against both surface water users and environmental impacts. Groundwater management institutions will need to be capable of setting clear objectives, garnering stakeholder support, and laying out a clear path for action.

Finally, governance requires ensuring the implementation of a plan. Groundwater agencies will need to put in place regulations, permits, and incentive programs and must be prepared to enforce plan implementation to ensure compliance. The ongoing monitoring of groundwater use and conditions will also be necessary to ensure that objectives are being met or to adjust implementation strategies. To make all of this possible, groundwater agencies will need to be designed with the jurisdictional authority and capacity to effectively carry out groundwater management activities. 


\section{Institutional Design}

Throughout this article, groundwater agency refers to a governance system-at the local level for the purposes of this article-that has responsibility for managing groundwater in specific local basin(s). A GSA is a groundwater agency developed in California under SGMA. Local entities refer to existing governmental bodies such as water districts, county governments, land use agencies, or any of the many other entities that have a potential role in groundwater management. State agencies refer to state-level bodies that oversee, assist, enforce, or otherwise influence the activities of groundwater agencies. Although many agencies and organizations will be involved in Californian groundwater management, the newly formed GSAs will be central and crucial, as they will have frontline responsibility for developing and implementing regulatory controls. As such, it is essential to ensure they are able to govern well.

Scholarship on the governance of natural resources has long investigated factors that affect processes of and outcomes from water governance. Common-pool resources such as groundwater [46] tend in particular to have low excludability (e.g., it is difficult to control access to the resource) and high subtractibility (e.g., use depletes the resource) [47]. Addressing the resulting challenges effectively requires frequent interactions among, and support for monitoring and enforcement by, resource users $[48,49]$. Evidence also shows that environmental governance systems are more resilient when they include structures that are adaptive, multi-level, and focused on learning [12,50]. Further, as natural resources use often involves political decisions, governance systems that include participation, collaboration, and deliberation tend to be more effective in achieving support for, and compliance with, management strategies [51,52]. Lastly, the effectiveness of governance systems is strengthened by legitimacy, transparency, accountability, inclusiveness, fairness, integration, and capability [53], increase the likelihood that the system will be trusted and its leaders respected.

Recently, two independent efforts have sought to translate insights from prior research and experiences into practicable recommendations for water governance. The Organisation for Economic Co-operation and Development (OECD) engaged water practitioners from around the world in the development of a set of twelve principles for water governance [52,54]. These principles, which are organized around the three elements of efficiency, effectiveness, trust and engagement, aim to help identify "whether water governance systems are performing optimally and help to adjust them where necessary" [54]. More specific to groundwater, Varady et al. [17] conducted a meta-analysis of 10 published case studies on groundwater governance to identify lessons learned regarding four elements of groundwater governance: (1) institutions; (2) information and science; (3) robustness of civil society; and (4) economic and regulatory frameworks. While both of these efforts provide valuable information, they are focused on defining what constitute good or effective governance and making recommendations on practices that achieve it.

In this article, our concern is with the enabling conditions that make it possible for groundwater governance systems to practice good governance. Thus, we focus on the institutional design of groundwater governance system, identifying key considerations local entities will need to deliberate as they determine the institutional structure for the new groundwater governance systems (GSAs) they are forming. We offer nine criteria that can be used as principles or standards in the evaluation of institutional design for local level groundwater governance: scale, human capacity, funding, authority, independence, participation, representation, accountability, and transparency. We group these criteria into two general categories: criteria most closely tied to the efficacy of governance (the first five in the list above) and criteria that primarily bear on the fairness of decisions (the final four from the list). The criteria are interrelated, overlapping, sometimes mutually supportive, and occasionally conflicting.

The criteria we present address many of same themes as the OECD and Varady et al. studies, yet differ in that they point to the relationship between institutional design and how a governance system is able to undertake governance, rather than being recommendations for specific governance activities. This distinction is nuanced. To make this distinction clear and to guide local entities as they make 
institutional design decisions, we translate the criteria a set of questions for local entities to ponder as they make their institutional design decisions.

Below, we describe each efficacy and fairness criterion at a conceptual level. While we include some specific references to SGMA, most of the observations are readily generalizable. Subsequent sections identify context and specific application under SGMA.

\section{Efficacy Criteria}

\subsection{Scale}

Scale refers to the spatial extent of a groundwater agency's jurisdiction relative to the resource being managed [55]. Scale will be a key consideration for GSAs as their boundaries will determine the geographic scope of the agency's influence and each GSA's relationship to the physical groundwater system being managed $[17,56]$.

Several factors influence the selection of jurisdictional boundaries. Scale is often considered in terms of a map view of the physical characteristics of a region, including the ground surface and some depth into the underlying geological units. However, recharge, surface-groundwater interactions, drivers of environmental degradation, and infrastructure that conveys water may not match the boundaries of these geologic units. Social characteristics commonly influence the selection of jurisdictional boundaries. The spatial extent of an agency's jurisdiction must be reconciled with adjacent, nearby, and overlapping jurisdictions of complementary and competing entities [56-58]. It may simply not be possible (or even always desirable) [59] to develop jurisdictional boundaries that align with both source water areas and aquifer boundaries; for example, where headwaters are distant. Lastly, the sheer size of some groundwater basins will influence the selection of boundaries. In large groundwater basins, practical impediments can exist to developing and operating a single groundwater agency, although some groundwater systems are managed at a large scale (e.g., Arizona's Active Management Areas) [60]. Differences in economics, political resources, culture, and other social factors may cause basin-wide strategies to be too cumbersome for the variety and dynamics within a basin [61-64]. Finally, political boundaries can be difficult to change once they are established; as a result, decisions regarding GSA scale are likely to be decided at an early stage in the planning process, before there is a holistic understanding of the associated physical and social issues.

\subsection{Human Capacity}

Human capacity is the ability of individuals and teams to successfully carry out tasks that enable an agency to achieve its mission. For newly formed GSAs in particular, staffing, expertise, administrative support, and other resources will be needed to develop knowledge of the groundwater system [17], set objectives and plan for the management of the system, and implement the management plan.

Groundwater agencies need to ensure that their personnel have the knowledge, expertise, and time required for the effective management of technical, legal, communication, and financial issues. This means that those agencies must develop a mixture of in-house talent in key areas, access to external expertise when needed for critical functions, and leadership that knows how to deploy human resources and encourage effective collaboration and creative problem solving on a routine basis. Groundwater agencies must decide how best to recruit and retain professional staff capable of developing the necessary experience with regional hydrologic conditions, politics, and infrastructure. These decisions may include looking to or relying on federal or state entities for temporary staff, guidance, and/or training; contracting with private firms with experience in hydrologic or management consulting; and collaborating or sharing staff with other regional agencies. As the development of human capacity comes with a cost, it will be critical to define needs so that plans and budgets can be aligned with the availability and timing of financial resources. 


\subsection{Funding}

Funding refers to the financial resources necessary to support governance. GSAs will need to fund analyses and project planning documents; the costs for education and outreach activities; capital expenditures such as the acquisition of land, facilities, or water rights; and ongoing expenses such as salaries, facility operations, and maintenance $[65,66]$. They will need a positive revenue stream to maintain governance functions in order to pay for professional staff, consultants, equipment, and other costs. In addition, if financial incentives are to be part of the groundwater governance system-for example, through creative rebate mechanisms to encourage additional aquifer recharge [67]—those incentives will require a funding source.

Underfunded governance institutions are common, and water is no exception [68]. GSAs need to build in funding mechanisms as part of their institutional design, and, in California, there are a range of options for doing so [69]. Under SGMA, user fees-perhaps tied to groundwater pumping or water use-are possible [66], though those have a history of arousing vigorous political and legal opposition and may require voter approval [70]. Grants from other levels of government can support GSAs, but these are often available for the support of individual (mainly, capital) projects rather than operations, maintenance, or other day-to-day activities. General taxpayer funding is another possibility, but it may not be an option if the governance system does not have the authority to levy taxes or if it is not politically feasible to levy a tax.

\subsection{Authority}

Authority refers to the legal permission and powers held by a groundwater agency that enables it to carry out its mission. Authority for resource management is usually mandated by a constitution, legislated by one or more bills, delegated from higher to lower (regional) authorities, or arises, in subsidiarity-based systems, because of the inherent powers of local governments. To function effectively, groundwater agencies need authority to tell groundwater users what they can and cannot do and to back those directives, if necessary, with enforcement. Without sufficient authority, the groundwater management system is likely to devolve into voluntarism, with the groundwater agencies doing little more than providing information and acting as cheerleaders for sustainable management.

Where local governments derive legal authority from the state, the state will need to delegate to them the powers necessary to govern groundwater. California delegates various authorities to GSAs, including the authority to restrict groundwater extractions [71]. The range of relevant authorities GSAs can draw on for their groundwater management under SGMA are detailed in [69]. Where GSAs are constituted from existing local governmental agencies, they may also have other existing authorities in addition to those granted by SGMA. GSAs also need to accept and act on the authorities available to them.

Beyond legal authority, groundwater agencies require social license to regulate. A groundwater agency without strong political support or respect among users may find it difficult to exercise what might appear, on paper, to be powerful legal leverage. Creating and maintaining social license requires sustained and effective outreach and engagement activities, being responsive to stakeholder concerns, and transparency and accountability in operations, as discussed below.

\subsection{Independence}

Independence is the ability of a groundwater agency to operate freely within its defined purview. Groundwater managers need to be able to make, and implement, controversial decisions without excessive interference from the groundwater users that they are supposed to regulate, from political figures operating on those users' behalf, or from other government entities with competing goals. Without that ability, groundwater managers are unlikely to impose restrictions on groundwater use or they may focus those restrictions on users who lack political influence. 
To address independence, GSAs can be formed as independent institutions, not subordinates of other governmental entities. To facilitate independence, GSAs can adopt conflict of interest rules, reserve management board slots for interest groups that are likely to be underrepresented, and provide strong public participation provisions. Similarly, limiting removal authority over board members, e.g., by giving board members fixed, staggered terms, can insulate managers from short-term political imperatives.

\section{Fairness Criteria}

\subsection{Participation}

Participation is direct, effectual stakeholder involvement in the decision-making process [52,72]. It can occur through comment letters, public meetings, or other mechanisms. Participation differs from representation (see below) in that it does not occur through the election or appointment of intermediaries to a governing body.

Broad participation is normatively important due to the diversity of people affected by, and with an interest in, groundwater management. The absence of participation can create a sense-often justified-that decisions are being made in secret [73,74]. Participation also builds capacity by bringing useful information to government decision makers [75]. Public participants can raise issues that decision-makers have not anticipated and thus can help avoid creating unnecessary problems. Participation will ideally help shape specific decisions such as identifying sustainability goals and measurable objectives.

Participation can be incorporated into a GSA's institutional design through a variety of mechanisms [76]. Outreach, including meeting announcements, public availability and access to relevant documents, and information on how interested parties can participate will facilitate stakeholder involvement. Regular opportunities for input and comment provide a forum for stakeholders to provide input to groundwater governance decisions. More formally, a groundwater agency can create advisory committees and solicit stakeholder participation on committees and boards. Stakeholders must have the capacity to participate [77], so GSAs can also support disadvantaged stakeholders by providing financial support, assistance with transportation, technical tutorials, and other resources that will facilitate their participation $[52,78]$.

\subsection{Representation}

Representation occurs when the interests of stakeholders are formally carried into the decision making process, either through direct voting or, more frequently, through representatives standing in for a broader population. A fair representation system gives voice, as much as is practically feasible, to the full range of interests that will be affected by the decision to be made, including interests not backed by money or power. Fair representation is essential for creating durable decisions. Inadequate representation could hinder the equitable distribution of the benefits and costs of management actions or could distort market mechanisms where they are employed [25]. Such actions could lead to unjust outcomes, unsustainable outcomes, extended and costly litigation, or action by the state, all of which would ultimately undermine the effectiveness of local governance.

For GSAs, addressing the challenges of representation requires thinking about how decisions will be made as well as considering who will participate as representatives. Using simple majority votes, for example, can result in different outcomes than making decisions by super majority or consensus [79]. The mechanisms available to GSAs to broaden representation include using neutral facilitators during agency formation, requiring disclosure — or even avoidance — of conflicts of interest, and requiring balanced representation within governing boards $[79,80]$. Other alternative schemes for representation under SGMA have been proposed to address specific challenges such as those which might emerge from trading systems [25]. GSAs could also consider including mechanisms to dismiss board members should stakeholders determine them not to be acting on behalf of the whole [25]. Representation measures overlap substantially with measures that can protect independence, and that is no coincidence: 
a groundwater agency with broad representation should be less prone to being captured by the interest groups it is supposed to regulate. The challenges of representation are likely to be particularly salient for the historically disadvantaged and marginalized communities that depend upon groundwater, which, in many parts of California, are often small rural communities with heavily Latino populations.

\subsection{Accountability}

Accountability occurs when groundwater agencies are held responsible for their decisions and actions and are answerable for their results. Accountability helps to ensure that groundwater agencies pursue the correct goals and make decisions that are consistent with governing laws, common sense, and basic principles of fairness [52,81]. Accountability can help identify if decisions or decision-making processes are succeeding or are in need of reform. Accountability also supports institutional credibility.

Groundwater agencies need to be externally and internally accountable. In terms of external accountability, GSAs must be answerable to groundwater users, other local entities, state agencies, and the public [69]. Internally, groundwater agencies will need procedures or mechanisms for ensuring that groundwater management activities align with the organizational mission and for ensuring that employees and consultants are doing their work properly and effectively. Having a clear policy direction, including formally adopting goals and policies through a public process, contributes to both external and internal accountability. Performance standards, documentation, proper procedures, public disclosure of data on actions taken and outcomes produced, incentives that reward success or sanction failure to meet benchmarks, and independent oversight and review of decisions can also contribute substantially to accountability [82].

\subsection{Transparency}

Transparency is operating with openness so that stakeholders, advisors, and those charged with operating the agency can understand how decisions are made, understand the implications of management and regulatory actions, and know how to make their concerns known $[83,84]$. Transparency generates clarity, knowledge, and trust and helps to support accountability and encourage participation, two other fairness criteria.

Transparency is a legal requirement for GSAs [69], and can be implemented using several techniques. At the most basic level, transparency involves setting priorities, developing projects, running meetings, sharing information, and voting on key decisions in accordance with established rules and laws. Regular outreach and public discussion of information, beyond satisfying minimal requirements such as those associated with receiving and responding to public comments on proposed infrastructure projects and environmental reviews, can increase transparency. New information technologies and systems for sharing and visualizing environmental data using interactive platforms can make information widely accessible and help to improve public understanding of that information. Making documents available in multiple languages, making information searchable, and providing metadata will help stakeholders understand how it was developed. Irrespective of the methods used, to ensure transparency is achieved, groundwater agencies need goals for and metrics of transparency, with documentation of achievements, shortcomings, and updated plans for improvement.

\section{Summary of Design Considerations for Groundwater Agencies}

The nine criteria described above highlight important considerations that influence the effectiveness of local groundwater governance. The criteria are presented as unique and independent but, in practice, are overlapping and interrelated. Some are mutually supportive; for example, transparency helps to reinforce accountability. Others have dependency relationships; for example, human capacity is highly dependent on funding. Others can lead to tension and tradeoffs. For example, choosing a more manageable scale may jeopardize the basis for funding, and transparency, if not implemented with care, may impact independence and general efficacy. As such, it is not possible to consider some of these criteria without also considering others. Nevertheless, local agencies will 
invariably need to make decisions during their formation that will have long-term influence on how they are able to manage groundwater: foresight will be crucial. These nine criteria can be viewed as a conceptual guide (Table 1) to help agencies and stakeholders think through the challenges and options faced by groundwater agencies. Given that the Sustainable Groundwater Management Act (SGMA) is specifically structured to foster diversity in solutions to match the diversity in groundwater challenges, a fully prescriptive approach would be inconsistent. Therefore, we frame the questions in Table 1 as neutral pointers that can help structure the thinking across a range of interested parties. Further details and supporting arguments are referred to in the text of this article and in [70].

Table 1. Evaluating the Institutional Design for Local Groundwater Governance. The condensed set of questions in this table reflects the criteria for evaluating options for groundwater governance. This list can be used as a starting point for decision-makers and stakeholders to engage in discussions about institutional design in the local governance paradigm described in the text.

\begin{tabular}{|c|c|}
\hline Criteria & Questions \\
\hline Scale & $\begin{array}{l}\text { - How do the boundaries of the groundwater agency compare to the boundaries of the groundwater basin } \\
\text { or sub-basin? } \\
\text { - What plans are in place to deal with any gaps in coverage, aquifers shared with other groundwater } \\
\text { agencies, or overlap with other related entities? } \\
\text { - What plans are in place to address connections between groundwater and surface water? } \\
\text { - How will the groundwater agency coordinate with land use planning and regulatory agencies within and } \\
\text { outside the basin on issues like well permitting and aquifer recharge? } \\
\text { What mechanisms will ensure effective coordination with neighboring groundwater agencies? }\end{array}$ \\
\hline $\begin{array}{l}\text { Human } \\
\text { capacity }\end{array}$ & $\begin{array}{l}\text { - What skills and expertise will be required during the formation and functioning of the groundwater agency? } \\
\text { - Will those capacities exist in the proposed groundwater agency? If not, how will those capacities be } \\
\text { developed or accessed? }\end{array}$ \\
\hline Funding & $\begin{array}{l}\text { - How much and what types of funding will likely be needed for the groundwater agency to fulfill its } \\
\text { functions over time? } \\
\text { - What access to funding is available to the groundwater agency? How does this align with projected } \\
\text { resource needs? }\end{array}$ \\
\hline Authority & $\begin{array}{l}\text { - What powers and authorities are available to the groundwater agency and under what circumstances will it } \\
\text { exercise them? } \\
\text { - How will the groundwater agency ensure that its authority is not duplicative of or conflicting with } \\
\text { pre-existing authorities and coordinate effectively with other entities with relevant authorities? } \\
\text { How will the groundwater agency enforce its decisions on groundwater users if they fail to provide the } \\
\text { required information or violate other requirements (e.g., pumping restrictions)? }\end{array}$ \\
\hline Independence & $\begin{array}{l}\text { - What mechanisms will ensure that the groundwater agency is capable of making difficult decisions } \\
\text { necessary to achieve sustainable groundwater management in the basin, even in the face of pressure from } \\
\text { competing interests? }\end{array}$ \\
\hline Participation & $\begin{array}{l}\text { - How will the groundwater agency ensure meaningful participation by a broad spectrum of groundwater } \\
\text { users and other affected stakeholders in its decision-making? } \\
\text { What capacities do stakeholders have, and what additional support do they need, to participate effectively } \\
\text { in all phases of the groundwater agency's activities? }\end{array}$ \\
\hline Representation & $\begin{array}{l}\text { - How will representatives be chosen? } \\
\text { - How will the groundwater agency ensure adequate representation of diverse stakeholder groups among the } \\
\text { - Wroundwater agency decision makers? } \\
\text { What role will representatives play in evaluating governance options? }\end{array}$ \\
\hline Accountability & $\begin{array}{l}\text { - What mechanisms will the groundwater agency put in place to ensure that its employees and consultants } \\
\text { do good work? } \\
\text { - What mechanisms will the groundwater agency put in place to ensure the effective oversight and } \\
\text { enforcement of fees, extraction limits, and other requirements it adopts? } \\
\text { - How will the groundwater agency measure progress toward sustainable management? } \\
\text { How will the groundwater agency be accountable to groundwater users and other stakeholders for the } \\
\text { success of its management actions? }\end{array}$ \\
\hline Transparency & $\begin{array}{l}\text { - How will the groundwater agency ensure transparent decision-making? } \\
\text { - What information will be disclosed and what information withheld from which stakeholders, decision } \\
\text { makers, and community groups and why? } \\
\text { - How will modeling assumptions and supporting data, including monitoring data, be communicated to } \\
\text { the public? }\end{array}$ \\
\hline
\end{tabular}




\section{Application of the Institutional Design Criteria to California under SGMA}

When applying the criteria articulated above, it is important to consider the larger structures in which groundwater agencies are embedded. Indeed, the way the new institutions are designed and implemented will depend on the context in which they form. In this section, we describe some elements surrounding the formation of new groundwater agencies in California as part of SGMA implementation and explain the ways in which those elements intersect with the nine criteria defined earlier. This discussion serves both to illustrate the applicability of our criteria to a real-world context and to explain some of the challenges California's GSAs will face. In California, GSAs will function within a framework that assigns important roles to state agencies and to non-governmental actors. In particular, legal guidelines and oversight and support from the state and other actors will influence institutional design choices. Nevertheless, many important institutional design choices remain subject to the discretion of local agencies.

\subsection{External Rules and Guidelines}

In California, GSAs do not have carte blanche to define their own structure and goals. The legal and regulatory foundation provided by SGMA is an important enabling tool in this top-down structure. The law and its attendant regulations direct GSAs to carry through their responsibilities, despite local political resistance, and also serve to influence a range of institutional design choices, particularly regarding scale, participation, and human capacity.

With respect to scale, SGMA directs GSAs to form and allows them to select the boundaries of their choosing; though, if multiple GSAs form within a single basin [85] , SGMA requires GSAs to coordinate to ensure that the resulting groundwater management achieves sustainability across the entire basin. The initial stages of this formation process are complete (see Section 9, below). The official boundaries of basins and sub-basins delineated by the California Department of Water Resources provided a structure within which GSAs selected their boundaries. In concept, it would be ideal to align hydrologic and jurisdictional boundaries so that the latter encompass the full range of activities that can influence groundwater flows and quality within the basin. Aligning basin and jurisdictional boundaries would also reduce the transaction costs associated with cooperative mechanisms such as memoranda of understanding or joint powers agreements [56]. However, physical, historical, and political realities are leading GSAs to develop governance with mismatched basin and jurisdictional scales [56].

SGMA also directs GSAs to incorporate public participation in their institutional design and decision-making. These provisions include a broad definition of interested parties and requirements for public hearings, notice, and documentation. Local agencies must hold public hearing(s) before forming a GSA or adopting or amending a groundwater sustainability plan (GSP). A GSA must 'consider the interests of all beneficial uses and users of groundwater', and these users are defined quite broadly [86]. GSAs must also notify the public as to how interested parties can participate in GSP development and implementation [87]. Furthermore, SGMA explicitly gives federally recognized Indian tribes the option for voluntary full participation in the preparation or administration of GSPs though a joint powers agreement (JPA) or other agreements with local agencies [88].

Additionally, SGMA requires GSAs to collect data and monitor and report on the state of the groundwater basin and develop GSPs that specify management goals and criteria, measurable objectives and milestones, and management areas and actions [89]. To ensure that these plans are implemented, SGMA grants GSAs the authority to use a wide variety of regulatory measures to ensure that the GSPs developed are implemented. The requirements for developing knowledge and the granting of authority to manage resources should enable GSAs to develop significant human capacity.

\subsection{Legal Structures for External Oversight}

The legal and regulatory foundation provided by SGMA also provides state agencies with robust authority for continuing oversight. The California Department of Water Resources and the California 
State Water Resources Control Board collectively play a backstop role, ensuring that the objectives of the legislation are achieved. Among other responsibilities, they must review local groundwater management plans, and, if those plans are inadequate, they must substitute their own. This structure contributes to the accountability and transparency of GSAs in ways that may not be available to purely self-governing groundwater institutions.

Specifically, a determination by the Department of Water Resources (DWR) that a GSA has not undertaken sufficient action will trigger the regulatory authority of the State Water Resources Control Board [90], which can impose probationary status. Requirements that GSAs set measureable objectives and interim milestones for achieving their objectives and that DWR provide technical oversight of GSA progress on those tasks also foster accountability by providing concrete metrics and external evaluation [91]. In combination, these measures provide state agencies with authority to demand more vigorous action by local agencies. Whether and how these agencies will in fact intervene remains a key open question for SGMA implementation [92], as does the potential for this intervention to motivate GSAs towards strong action.

Beyond direct oversight, SGMA and other California laws also encourage accountability and transparency through provisions that enable oversight by non-state entities. Accountability mechanisms include the potential for challenge by citizens, judicial review, and acknowledgement of the authority of other governmental agencies and regulations that impact groundwater governance [69]. SGMA also requires DWR to develop best management practices for GSAs, which include requiring documentation of actions taken by the GSAs and outcomes produced, independent review, external audits, and public disclosure. Moreover, SGMA and other California laws provide for process transparency by requiring open meetings and allowing for public records requests [69].

\subsection{External and Internal Support}

In California, the state, along with a range of non-governmental actors, is committing significant resources to support both the formation and the functioning of the GSAs. This external support will help bolster the limited funding and human capacity of the emerging local groundwater institutions. DWR is providing data, information, and technical support to GSAs. Professional state-funded facilitators are available to assist in local institutional design processes. DWR is developing a set of best management practices to provide clarification, guidance, and examples to help GSAs develop their plans. External funding sources, including funds available from state bonds, are being directed to local groundwater projects, although, in California, facilitation and legal guidance will be crucial to developing sustainable long-term local funding streams. Foundations and government sources are investing in research, demonstration projects, advocacy, and other activities intended to support the successful implementation of SGMA.

Over the long term, GSAs will have to develop sustainable funding models that assure support for staff, consultants, infrastructure (capital, operation, and maintenance), and public engagement. For much of California's history and in most of the state, pumping groundwater has required payment mainly of basic costs for well drilling and installation, pumps and power, and local conveyance. Under SGMA, many GSAs will devise plans to monetize their activities and the pumping of groundwater itself as a means to support the implementation of GSPs. One of the key promises of local governance is its potential to enable innovative approaches to management, and it is through creative efforts to monetize GSA activities that innovation may most quickly emerge; for example, through the development of new mechanisms to incentivize recharge [67,92]. These financial models are likely to be tested by public and legal challenges and will require that particular attention be paid to criteria of transparency, accountability, and participation.

\section{Conclusions}

California's experience with SGMA is a grand experiment, the results of which will unfold across decades. GSAs have only just been constituted, and their sustainability plans will not be finalized for 
several years, but initial data on GSA formation reflect early decisions regarding scale and participation. In over $99 \%$ of the high- and medium-priority basins in the state, GSAs met the June 2017 deadline to submit their formation documents to DWR [93], with 262 new GSAs forming to cover 140 groundwater basins [94]. DWR had classified the majority of GSAs as exclusive (non-overlapping) as of September 2017, but overlap between the boundaries of GSAs has yet to be reconciled in at least six basins, and dozens of GSAs have yet to be classified. Preliminary analysis of GSA formation prior to the formation deadline suggested that fragmentation is prevalent; many existing local entities have, at least initially, chosen to retain their existing jurisdictional boundaries rather than to consolidate around basin boundaries [56].

However, many institutional design decisions have yet to be made. As reflected in the GSA formation notices [94], most GSAs have yet to decide upon institutional and administrative structures and processes, including how to address the majority of the efficacy and fairness criteria we have identified. GSAs will need to address these decisions during the next three to five years, as they develop and then implement their groundwater sustainability plans.

As California implements SGMA, we will learn a great deal about how decisions are made for groundwater management [92]. This process presents a rich opportunity for research, including testing and empirically evaluating the positions developed in this article. Research questions can be developed directly from each of the criteria described in this article. To the extent that research can evaluate what design choices GSAs areas make and why they make them, it will help to evaluate the validity of the criteria described here. The significance of such research will lie in part in the opportunity to link normative notions for institutional design explicitly to both policies and practices that are ultimately adopted by GSAs, as well as to the ultimate test of SGMA's local-level governance model, namely, the GSAs' success at achieving SGMA's goals for the sustainable management of groundwater.

Beyond the specifics of California's experience, SGMA provides a model for other areas to look to as they make decisions about whether and how to develop self-governing institutions for groundwater governance. To some extent, groundwater basins in California have already run the alternative experiment over the last 160 years, a period without a unifying statewide framework for groundwater management. The results of that experiment are readily apparent; while bright spots exist [30], groundwater supplies, quality, and associated hydrologic systems have suffered in many basins. As we have argued, careful attention to governance and institutional design will be an important ingredient in determining whether or not this next chapter in California's experimentation with groundwater management will result in sustainability.

Acknowledgments: We thank Andrea Gerlak, William Alley, and anonymous reviewers for constructive suggestions on previous versions. This work was partly supported by the University of California Office of the President (UCOP) through the UC Water Security and Sustainability Research Initiative (UCOP Grant Number 13941), by the Gordon and Betty Moore Foundation, Grant GBMF5595, and by the USDA National Institute of Food and Agriculture AFRI project 1012412.

Author Contributions: Michael Kiparsky, Anita Milman, Dave Owen and Andrew T. Fisher jointly wrote the paper and also contributed, along with Nell Green Nylen, Juliet Christian-Smith, Barbara Cosens, and Holly Doremus, to a UC Berkeley study on which this article builds. That study is entitled Designing Effective Groundwater Sustainability Agencies: Criteria for Evaluation of Local Governance Options and is available at clee.berkeley.edu.

Conflicts of Interest: The authors declare no conflicts of interest.

\section{References and Notes}

1. Famiglietti, J.S. The global groundwater crisis. Nat. Clim. Chang. 2014, 4, 945-948. [CrossRef]

2. Siebert, S.; Burke, J.; Faures, J.M.; Frenken, K.; Hoogeveen, J.; Döll, P.; Portmann, F.T. Groundwater use for irrigation-A global inventory. Hydrol. Earth Syst. Sci. 2010, 14, 1863-1880. [CrossRef]

3. Alley, W.M.; Healy, R.W.; LaBaugh, J.W.; Reilly, T.E. Flow and Storage in Groundwater Systems. Science 2002, 296, 1985-1990. [CrossRef] [PubMed]

4. Wada, Y.; Van Beek, L.P.H.; Van Kempen, C.M.; Reckman, J.W.T.M.; Vasak, S.; Bierkens, M.F.P. Global depletion of groundwater resources. Geophys. Res. Lett. 2010, 37. [CrossRef] 
5. Konikow, L.F.; Kendy, E. Groundwater depletion: A global problem. Hydrogeol. J. 2005, 13, 317-320. [CrossRef]

6. Foster, S.; Chilton, J.; Nijsten, G.J.; Richts, A. Groundwater-A global focus on the 'local resource'. Curr. Opin. Environ. Sustain. 2013, 5, 685-695. [CrossRef]

7. Groundwater Governance. Global Diagnostic on Groundwater Governance; Groundwater Governance-A Global Framework for Action. Available online: http:/ / www.groundwatergovernance.org/ (accessed on 30 September 2017).

8. Megdal, S.B.; Gerlak, A.K.; Varady, R.G.; Huang, L.Y. Groundwater Governance in the United States: Common Priorities and Challenges. Ground Water 2015, 53, 677-684. [CrossRef] [PubMed]

9. Hoogesteger, J.; Wester, P. Intensive groundwater use and (in)equity: Processes and governance challenges. Environ. Sci. Policy 2015, 51, 117-124. [CrossRef]

10. Foster, S.; Garduño, H. Groundwater-resource governance: Are governments and stakeholders responding to the challenge? Hydrogeol. J. 2013, 21, 317-320. [CrossRef]

11. Alley, W.M.; Alley, R. High and Dry: Meeting the Challenges of the World's Growing Dependence on Groundwater; Yale University Press: New Haven, CT, USA, 2017.

12. Lebel, L.; Anderies, J.; Campbell, B.; Folke, C.; Hatfield-Dodds, S.; Hughes, T.; Wilson, J. Governance and the Capacity to Manage Resilience in Regional Social-Ecological Systems. Ecol. Soc. 2006, 11, 19. [CrossRef]

13. Lemos, M.C.; Agrawal, A. Environmental Governance. Ann. Rev. Environ. Resour. 2006, 31, $297-325$. [CrossRef]

14. Helmke, G.; Levitsky, S. Informal institutions and comparative politics: A research agenda. Perspect. Politics 2004, 2, 725-740. [CrossRef]

15. Alexander, E.R. Institutional Transformation and Planning: From Institutionalization Theory to Institutional Design. Plan. Theory 2005, 4, 209-223. [CrossRef]

16. Weimer, D.L. Institutional design: Overview. In Institutional Design; Springer: Berlin, Germany, 1995; pp. 1-16.

17. Varady, R.; Zuniga-Teran, A.; Gerlak, A.; Megdal, S. Modes and Approaches of Groundwater Governance: A Survey of Lessons Learned from Selected Cases across the Globe. Water 2016, 8, 417. [CrossRef]

18. Nelson, R.L.; Perrone, D. Local Groundwater Withdrawal Permitting Laws in the South-Western U.S.: California in Comparative Context. Ground Water 2016, 54, 747-753. [CrossRef] [PubMed]

19. Ashley, J.S.; Smith, Z.A. Groundwater Management in the West; University of Nebraska Press: Lincoln, NE, USA, 1999.

20. Llamas, M.R.; Martínez-Santos, P. Intensive groundwater use: Silent revolution and potential source of social conflicts. J. Water Resour. Plan. Manag. 2005, 131, 337-341. [CrossRef]

21. Hill, C.; Furlong, K.; Bakker, K.; Cohen, A. Harmonization Versus Subsidiarity in Water Governance: A Review of Water Governance and Legislation in the Canadian Provinces and Territories. Can. Water Resour. J. 2008, 33, 315-332. [CrossRef]

22. Hannan, M.T.; Freeman, J. Structural Inertia and Organizational Change. Am. Sociol. Rev. 1984, 49, 149-164. [CrossRef]

23. Berkhout, F.; Hertin, J.; Gann, D.M. Learning to Adapt: Organisational Adaptation to Climate Change Impacts. Clim. Chang. 2006, V78, 135-156. [CrossRef]

24. Huntjens, P.; Pahl-Wostl, C.; Rihoux, B.; Schlüter, M.; Flachner, Z.; Neto, S.; Koskova, R.; Dickens, C.; Nabide Kiti, I. Adaptive Water Management and Policy Learning in a Changing Climate: A Formal Comparative Analysis of Eight Water Management Regimes in Europe, Africa and Asia. Environ. Policy Gov. 2011, 21, 145-163. [CrossRef]

25. Young, M.; McAteer, B. Sharing Groundwater: A Robust Framework and Implementation Roadmap for Sustainable Groundwater Management in California; Duke University: Durham, NC, USA, 2017.

26. Garner, E.L. Adapting water laws to increasing demand and a changing climate. Water Int. 2016, 41, 883-899. [CrossRef]

27. Sax, J.L. We Don't Do Groundwater: A Morsel of California Legal History. Univ. Denver Water Law. Rev. 2002, 6, 269.

28. Leahy, T.C. Desperate Times Call for Sensible Measures: The Making of the California Sustainable Groundwater Management Act. Golden Gate Univ. Envtl. L.J. 2015, 9, 5.

29. Littleworth, A.L.; Garner, E.L. California Water II; Solano Press: Point Arena, CA, USA, 2007. 
30. Nelson, R. Uncommon Innovation: Developments in Groundwater Management Planning in California; Woods Institute for the Environment: Stanford, CA, USA, 2011.

31. Ostrom, E. Governing the Commons: The Evolution of Institutions for Collective Action; Cambridge University Press: Cambridge, UK, 1990.

32. Langridge, R.; Brown, A.; Rudestam, K.; Conrad, E. An Evaluation of California's Adjudicated Groundwater Basins. State Water Resources Control Board. Available online: http:/ / www.water.ca.gov/cagroundwater/ docs/UCSC_Adjudicated_Groundwater_Basins_Report_FINAL.pdf (accessed on 30 September 2017).

33. Cal. Water Code $\S 10721(\mathrm{r})$; (v).

34. Cal. Water Code $\$ 10721(\mathrm{x})$.

35. Cal. Water Code $\S \S 10727.2(\mathrm{~b}) ; 10721(\mathrm{u})-(\mathrm{x})$.

36. Cal. Water Code $\S \S 113 ; 10720.1$.

37. Green Nylen, N. California's New Groundwater Law: An Interactive Timeline; UC Berkeley School of Law: Berkeley, CA, USA, 2014.

38. Fogg, G.E. Groundwater flow and sand body interconnectedness in a thick, multiple-aquifer system. Water Resour. Res. 1986, 22, 679-694. [CrossRef]

39. Anderson, M.P.; Woessner, W.W.; Hunt, R.J. Applied Groundwater Modeling: Simulation of Flow and Advective Transport; Academic Press: Cambridge, MA, USA, 2015.

40. Erskine, J.; Fisher, A. Implications of geometry, age and depositional history of a shallow confining layer in a coastal groundwater basin, Monterey County, California, USA. Geophys. Res. Lett. 2002, 29, 31-1-31-4. [CrossRef]

41. Konikow, L.; August, L.; Voss, C. Effects of clay dispersion on aquifer storage and recovery in coastal aquifers. Transp. Porous Media 2001, 43, 45-64. [CrossRef]

42. Klingbeil, R.; Kleineidam, S.; Asprion, U.; Aigner, T.; Teutsch, G. Relating lithofacies to hydrofacies: Outcrop-based hydrogeological characterisation of Quaternary gravel deposits. Sediment. Geol. 1999, 129, 299-310. [CrossRef]

43. Sivapalan, M.; Savenije, H.H.G.; Blöschl, G. Socio-hydrology: A new science of people and water. Hydrol. Process. 2012, 26, 1270-1276. [CrossRef]

44. Bredehoeft, J.D.; Papadopulos, S.S.; Cooper, H., Jr. Groundwater: The water budget myth. Sci. Basis Water Resour. Manag. 1982, 51, 57.

45. Milman, A.; Scott, C. Beneath the surface: Intranational institutions and management of the United StatesñMexico transboundary Santa Cruz aquifer. Environ. Plan. C Gov. Policy 2010, 28, 528-551. [CrossRef]

46. Ostrom, E. Public Entrepreneurship: A Case Study in Ground Water Basin Management. Ph.D. Thesis, University of California, Los Angeles, CA, USA, 1965.

47. Ostrom, E. Understanding Institutional Diversity; Princeton University Press: Princeton, NJ, USA, 2005.

48. Dietz, T.; Ostrom, E.; Stern, P.C. The Struggle to Govern the Commons. Science 2003, 302, 1907-1912. [CrossRef] [PubMed]

49. Ostrom, V.; Ostrom, E. Public goods and Public Choices; Rowman \& Littlefield: Lanham, MA, USA, 1977; pp. 7-49.

50. Huntjens, P.; Lebel, L.; Pahl-Wostl, C.; Camkin, J.; Schulze, R.; Kranz, N. Institutional design propositions for the governance of adaptation to climate change in the water sector. Glob. Environ. Chang. 2012, 22, 67-81. [CrossRef]

51. Armitage, D.; Marschke, M.; Plummer, R. Adaptive co-management and the paradox of learning. Glob. Environ. Chang. 2008, 18, 86-98. [CrossRef]

52. Akhmouch, A.; Clavreul, D. Stakeholder Engagement for Inclusive Water Governance: 'Practicing What We Preach' with the OECD Water Governance Initiative. Water 2016, 8, 204. [CrossRef]

53. Lockwood, M. Good governance for terrestrial protected areas: A framework, principles and performance outcomes. J. Environ. Manag. 2010, 91, 754-766. [CrossRef]

54. Organisation for Economic Co-operation and Development. OECD Principles on Water Governance; Organisation for Economic Co-operation and Development, Directorate for Public Governance and Territorial Development: Paris, France, 2015.

55. Gibson, C.C.; Ostrom, E.; Ahn, T.K. The concept of scale and the human dimensions of global change: A survey. Ecol. Econ. 2000, 32, 217-239. [CrossRef] 
56. Conrad, E.; Martinez, J.; Moran, T.; DuPraw, M.; Ceppos, D.; Blomquist, W. To Consolidate or Coordinate? Status of the Formation of Groundwater Sustainability Agencies in California; Stanford University: Stanford, CA, USA, 2016.

57. Adger, W.N.; Brown, K.; Tompkins, E.L. The political economy of cross-scale networks in resource comanagement. Ecol. Soc. 2005, 10, 9. [CrossRef]

58. Liverman, D. Who Governs, at What Scale and at What Price? Geography, Environmental Governance, and the Commodification of Nature. Ann. Assoc. Am. Geogr. 2004, 94, 734-738. [CrossRef]

59. Doremus, H. CALFED and the quest for optimal institutional fragmentation. Environ.Sci. Policy 2009, 12, 729-732. [CrossRef]

60. Jacobs, K.L.; Holway, J.M. Managing for sustainability in an arid climate: Lessons learned from 20 years of groundwater management in Arizona, USA. Hydrogeol. J. 2004, 12, 52-65. [CrossRef]

61. Lankford, B.; Hepworth, N. The cathedral and the bazaar: Monocentric and polycentric river basin management. Water Altern. 2010, 3, 82.

62. Blomquist, W.; Schlager, E. Political Pitfalls of Integrated Watershed Management. Soc. Nat. Resour. 2005, 18, 101-117. [CrossRef]

63. Molle, F. Nirvana concepts, storylines and policy models: Insights from the water sector. Water Altern. 2008, 1, 131.

64. Davidson, S.L.; De Loë, C. Watershed governance: Transcending boundaries. Water Altern. 2014, 7, 367-387.

65. California Department of Water Resources. Funding Programs for California's Sustainable Groundwater Management Act (SGMA); California Department of Water Resources: Sacramento, CA, USA, 2015.

66. Cal. Water Code $\S 10730$.

67. Fisher, A.T.; Coburn, C.; Kiparsky, M.; Lockwood, B.S.; Bannister, M.; Camara, K.; Lozano, S. Recharge Net Metering to Incentivize Sustainable Groundwater Management. In Proceedings of the Fall Meeting, San Francisco, CA, USA, 15 December 2016.

68. Hanak, E.; Gray, B.; Lund, J.; Mitchell, D.; Chappelle, C.; Fahlund, A.; Jessoe, K.; Medellín-Azuara, J.; Misczynski, D.; Nachbaur, J.; et al. Paying for Water in California; Public Policy Institute of California: Sacramento, CA, USA, 2014; p. 81.

69. Kiparsky, M.; Owen, D.; Nylen, N.G.; Cosens, B.; Doremus, H.; Fisher, A.; Christian-Smith, J.; Milman, A. Designing Effective Groundwater Sustainability Agencies: Criteria for Evaluation of Local Governance Options; Center for Law, Energy \& the Environment, University of California at Berkeley: Berkeley, CA, USA, 2016; p. 64.

70. Cal. Farm Bureau Federation v. Cal. St. Water Resources Control Bd. 247 P.3d 112 (Cal. 2011).

71. Cal. Water Code $\S 10726.4($ a).

72. Arnstein, S.R. A ladder of citizen participation. J. Am. Inst. Plan. 1969, 35, 216-224. [CrossRef]

73. Planning and Conservation League v. Dep't of Water Res. 100 Cal. Rptr. 2d 173. Cal. Ct. App. 2000.

74. Rossmann, A. Third District Court Of Appeal Strikes Down Monterey Amendment EIR, Restores Public Role In State Water Project. Calif. Water Law Policy 2000, 25, Reporter 29.

75. Simon, A.E. Valuing public participation. Ecology Law Q. 1998, 25, 757.

76. Dobbin, K.; Clary, J.; Firestone, L.; Christian-Smith, J. Collaborating for Success: Stakeholder Engagement for Sustainable Groundwater Management Act Implementation; Community Water Center: Visalia, CA, USA; Clean Water Fund: Washington, DC, USA; Union of Concerned Scientists: Cambridge, MA, USA, 2015.

77. Cal Water Code $\S 10727.8$.

78. Jeffery, M.I. Intervenor funding as the key to effective citizen participation in environmental decision-making: Putting the people back into the picture. Ariz. J. Int. Comp. Law 2002, 19, 643.

79. Kincaid, V.; Stager, R. Know Your Options: A Guide to Forming Groundwater Sustainability Agencies; California Water Foundation: Sacramento, CA, USA, 2015.

80. Cal. Wat. Code $\S 10723.2$.

81. Rhodes, R.A.W. Understanding Governance: Policy Networks, Governance, Reflexivity and Accountability; Open University Press: Philadelphia, PA, USA, 1997.

82. Christian-Smith, J.; Abhold, K. Union Concerned Scientists, Measuring What Matters: Setting Measurable Objectives to Achieve Sustainable Groundwater Management in California; Union of Concerned Scientists: Oakland, CA, USA, 2015. 
83. Kosack, S.; Fung, A. Does Transparency Improve Governance? Ann. Rev. Political Sci. 2014, $17,65-87$. [CrossRef]

84. Brandeis, L.D. What Publicity Can Do. Harper's Weekly, 20 December 1913, pp. 10-13.

85. Cal. Water Code $\S 10727.6$.

86. Cal. Water Code $\S 10723.2$.

87. Cal. Water Code $\S 10727.8$.

88. Cal. Water Code $\S 10720.3(\mathrm{c})$.

89. Cal. Code Regs., Title 23, Division 2, Chapter 1.5 Sub 2 § 350.

90. Cal. Government Code $\S 10735.2$.

91. Cal. Government Code $\S \S 10727.2 ; 10733.8$.

92. Kiparsky, M. Unanswered questions for implementation of the Sustainable Groundwater Management Act. Calif. Agric. 2016, 70, 165-168. [CrossRef]

93. California State Water Resources Control Board. California Achieves Major Milestone Toward Sustainable Groundwater Management; California State Water Resources Control Board: Sacramento, CA, USA, 2017.

94. California Department of Water Resources. SGMA Portal, GSA Formation Notification System. Available online: http:/ /sgma.water.ca.gov / portal/\#gsa (accessed on 6 September 2017).

(C) 2017 by the authors. Licensee MDPI, Basel, Switzerland. This article is an open access article distributed under the terms and conditions of the Creative Commons Attribution (CC BY) license (http:/ / creativecommons.org/licenses/by/4.0/). 